\title{
Florida Strawberry Growers Need More Early Yield to Improve Profitability ${ }^{1}$
}

\author{
Feng Wu, Zhengfei Guan, and Vance Whitaker ${ }^{2}$
}

\section{Introduction}

Fresh strawberries are a major US fruit crop planted across 52,500 acres with a farm gate value of $\$ 2.06$ billion in 2016. Due to its mild winter climate, Florida is the largest producer of winter strawberries in the United States, with a production area of approximately 10,700 acres and a farm gate value of $\$ 450$ million in 2016 . Florida traditionally markets fresh strawberries from late November until late March. However, that exclusive market window has been shrinking during the last few years, as Mexico has become a major competitor. Imports of fresh strawberries from Mexico reached 362 million pounds in 2016. This volume is approximately four times higher than Mexico's import volume a decade ago and one and a half times Florida production. Along with market integration, rapidly rising imports and domestic production have depressed market prices (Suh et al. 2017) and in some seasons have caused significant losses for Florida growers. Because fresh strawberries are a highly perishable commodity that cannot be stored for more than a few days, strawberry yield patterns have direct and strong effects on market prices.

This publication summarizes recent research (Wu et al. 2015) on strawberry yield patterns and how they are predicted to affect profits. It is intended primarily for those involved in Extension, marketing, policy-making, production, and research related to the Florida strawberry industry. We believe that a better understanding of yield and price dynamics will be valuable to industry decision-makers.

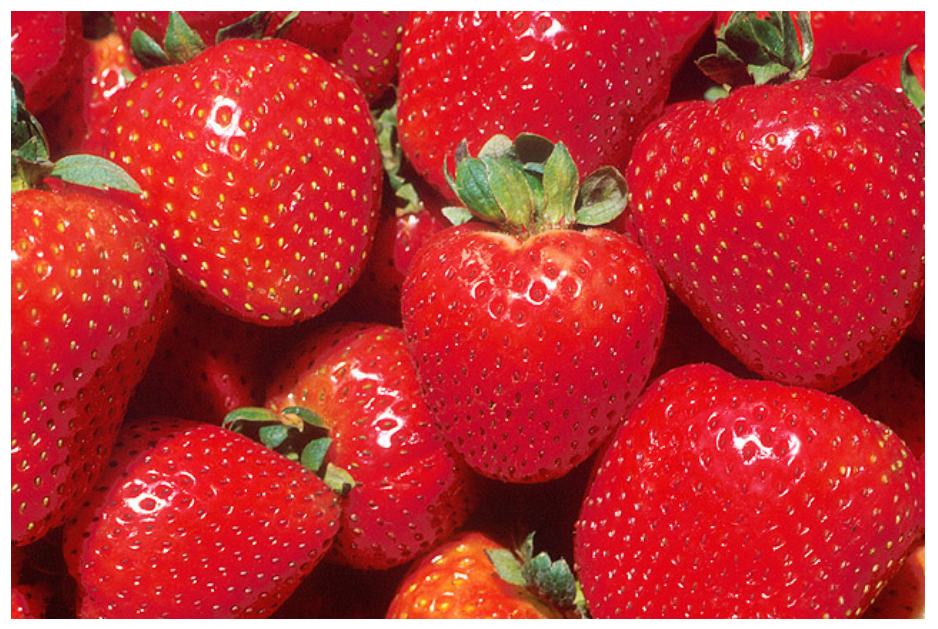

Credits: USDA

\section{Current and Optimal Yield Patterns}

Figure 1 illustrates strawberry supplies from Florida, Mexico, and California averaged over the four-year period 2013-2016. Florida strawberries are available starting in November. They peak in February and March and decline rapidly in late March and early April due to plummeting

1. This document is FE1032, one of a series of the Food and Resource Economics Department, UF/IFAS Extension. Original publication date September 2017. Visit the EDIS website at http://edis.ifas.ufl.edu.

2. Feng Wu, research assistant scientist, Food and Resource Economics Department; Zhengfei Guan, assistant professor, Food and Resource Economics Department; and Vance Whitaker, associate professor Horticultural Sciences Department, UF/IFAS Gulf Coast Research and Education Center, Balm, FL.

The Institute of Food and Agricultural Sciences (IFAS) is an Equal Opportunity Institution authorized to provide research, educational information and other services

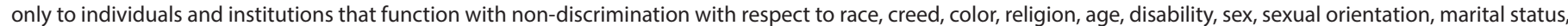

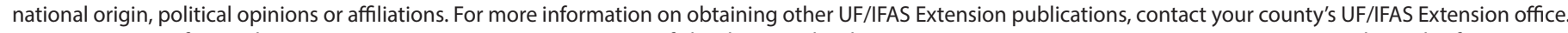
U.S. Department of Agriculture, UF/IFAS Extension Service, University of Florida, IFAS, Florida A \& M University Cooperative Extension Program, and Boards of County Commissioners Cooperating. Nick T. Place, dean for UF/IFAS Extension. 
prices. Imports from Mexico have almost the same pattern as Florida strawberries. In other months, imported Mexican strawberries are still available, but volumes are small.

California is the major producer for summer strawberries, with supply substantially decreasing in winter. Overall supply reaches its lowest point in November, gradually increases afterward, and peaks in March (Figure 1). Low supply in November and December contributes to strong early-season prices for Florida strawberries.

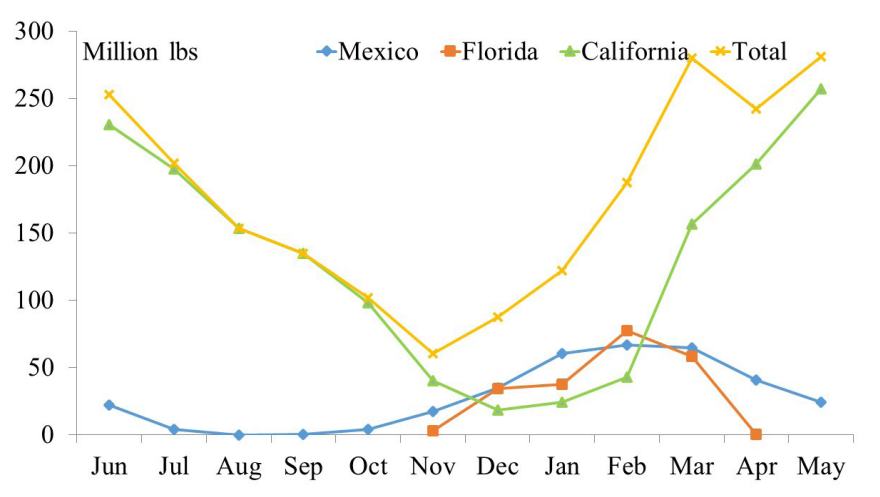

Figure 1. Four-year average (2013-2016) supply from California, Florida, and Mexico to the US market.

Figure 2 illustrates the dynamics of market average prices for 2013 through 2016. November and December have the highest prices, approximately $\$ 24 /$ flat ( 1 flat $=8$ pounds). Prices in March are reduced to less than half of the late November peak. Large price differences over the course of the season have made early-season yield critical to Florida growers' profitability. Accordingly, we have observed that the planting window in west-central Florida has shifted earlier in recent years, from early October to late September, in an attempt to produce higher yields in late November and early December.

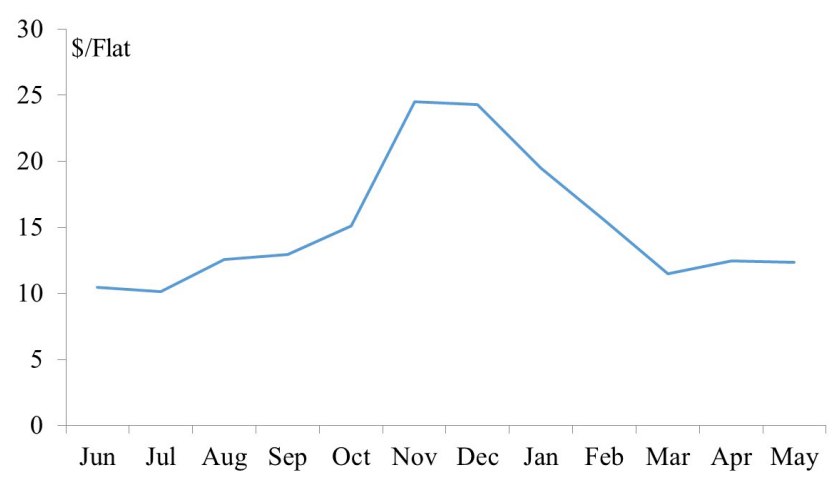

Figure 2. Four-year average (2013-2016) farm gate prices.
Meanwhile, overproduction in February and March has caused oversupply. In a perishable product market where long-term storage is not possible, all product is sold in a short period, which drives down prices in periods of oversupply. This oversupply problem has been exacerbated in recent years. Florida production jumped in 2011/12, which, along with climbing imports from Mexico, led to a market crash. Growers reported that more than 600 flats per acre were not harvested during the season because of a combination of lower prices and other factors (Guan et al. 2015). Six hundred flats represented a $20 \%$ yield loss. Some growers indicated that they had to abandon as much as $60 \%$ of strawberries in some of their fields.



Figure 3. Historical mean yield pattern vs. optimal yield pattern.

Given competition from California and Mexico and sensitive price responses to market supply, it is important to optimize the Florida yield distribution over the season. Wu et al. (2015) made an effort to derive optimal strawberry yield curves that maximize the revenues of Florida strawberry growers. Figure 3 compares the average historical yield pattern in Florida with the optimal yield distribution. First, the optimal yield curve requires growers to produce as much as possible in the early season in late November and early December. Early-season fruit receives high prices, but the overall supply on the US market is at its lowest; therefore, price decreases relatively slowly when yield increases. The effect of higher early yields on the gross margin is therefore very positive. Second, yields should ideally remain stable during the rest of the season (January, February, and March). Stabilization is necessary to prevent oversupply and price crashes because revenue from an increase in supply will be balanced by losses from lower prices. 
When yield follows the optimal distribution, the "harvesting gross margin" (i.e., sales minus harvest and post-harvest marketing cost) will be maximized with a value of $\$ 9,863$ / acre (from which pre-harvest production cost is yet to be deducted to obtain net profit). In contrast, the gross margin would be $\$ 6,753$ /acre if the yield distribution follows the historical average pattern. This means that a new strawberry variety or production practices that achieve the optimal yield distribution could generate an extra $\$ 3,110$ / acre. With a major technological breakthrough in early yield improvement in which yield could begin two weeks earlier than the optimal curve shown, as early as midNovember, growers could achieve significantly higher gross margins reaching $\$ 12,537 /$ acre, or $\$ 5,784$ higher than the historical benchmark. These findings highlight the critical importance of yield distribution to growers' profitability.

\section{Implications and Conclusions}

These findings on optimal yield pattern are consistent with the dynamics of variety adoption in Florida in recent years (Chandler et al. 1997, 2009). For instance, the yield pattern of 'Florida Radiance' is more compatible with the optimal yield curve than that of 'Strawberry Festival'. Indeed, 'Florida Radiance' replaced 'Strawberry Festival' as the leading cultivar grown in central Florida in 2012. If this pattern holds true, new release 'Florida Beauty', which can be planted earlier than current varieties, could possibly replace some 'Florida Radiance' acreage in upcoming seasons. Clearly, additional genetic gains for early-season yield should be a breeding priority. In addition, changes in horticultural practices and in marketing may also help achieve optimal yield distributions. Florida growers have historically used solid black mulch to cover planting beds for heat retention during cold weather. Mulch with a white center strip is currently being tested for early plantings to reduce crown temperatures early in the season and improve early flower initiation and fruit set. Growers are also shifting their contracted nursery production toward regions of the United States and Canada that produce transplants more likely to result in higher yield. The diversion of some Florida production to the processing market rather than the fresh market during late-season periods of high supply is being increasingly practiced. New markets and products using processed strawberries could be beneficial to profitability. These and other technological and market innovations should help Florida growers improve distributions of fresh strawberry supplies and, as a result, improve profitability in years to come.

\section{References}

Chandler, C.K., E.E. Albregts, C.M. Howard, and J.K. Brecht. 1997. "Sweet Charlie Strawberry." HortScience 32: $1132-1133$

Chandler, C.K., B.M. Santos, N.A. Peres, C. Joquand, A. Plotto, and C.A. Sims.2009. "Florida Radiance Strawberry." HortScience 44: 1769-1770

Guan, Z., F. Wu, F. Roka, and A. Whidden. 2015. "Agricultural Labor and Immigration Reform." Choices 30(4): 1-9.

Suh, D.H., Z. Guan, and H. Khachyatran. 2017. "The Impact of Mexican Competition on the US Strawberry Industry." International Food and Agribusiness Management Review 20: 591-604.

Wu, F., Z. Guan, and V. Whitaker. 2015. "Optimizing Yield Distribution under Biological and Economic Constraints: Florida Strawberries as a Model for Perishable Commodities." Agricultural Systems 141: 113-120. 